\title{
EFEKTIFITAS PROGRAM MANAGEMENT BY OBJECTIVES PADA TINGKAT WORK ENGAGEMENT KARYAWAN PT. X ICE CREAM YOGYAKARTA
}

\author{
Genjadid Utomo $^{1}$, Bagus Riyono ${ }^{2}$, Sus Budiharto ${ }^{3}$ \\ Fakultas Psikologi dan Ilmu Sosial Budaya, Universitas Islam Indonesia \\ genjadid.utomo@gmail.com
}

PT. X merupakan Usaha Kecil Menengah (UKM) yang sedang berkembang. Permasalahan yang dihadapi PT. X berkaitan dengan kurang optimalnya kinerja para karyawan. Penting bagi perusahaan tersebut untuk meningkatkan work engagement karyawan terutama untuk memastikan keberlangsungan usaha dan membuat karyawan memiliki kinerja yang optimal. Penelitian ini bertujuan untuk melihat efektifitas program management by objectives $(\mathrm{MBO})$ pada tingkat work engagement karyawan di PT. X. Penelitian ini menggunakan metode eksperimen dengan desain penelitian one group pre test-post test design. Subjek penelitian berjumlah 12 responden dari perusahaan Usaha Kecil Menengah yang bergerak di bidang beverage terlibat dalam Program $M B O$ yang dilakukan selama 2 bulan. Metode pengumpulan data dengan menggunakan skala UWES (Utrecht Work Engagement Scale) yang dikembangkan oleh Schaufeli dan Bakker. Analisis data menggunakan wilcoxon dan hasilnya menunjukkan bahwa program $\mathrm{MBO}$ efektif untuk meningkatkan work engagement karyawan $(-2.135 ; \mathrm{p}<0,05)$.

Kata kunci: $M B O$, management by objectives, work engagement

PT. $X$ is the small and medium enterprises (SMEs) are being developed. Problems faced by PT. $X$ relates is less than optimal performance of employees. It is important for these companies to increase employee engagement to ensure business continuity and to make employees have optimal performance. This study aimed to examine the effectiveness of program management by objectives (MBO) at the level of work engagement of employees at PT. X. This research used experimental methods with one group pre test-post test design. The subjects of the study were 12 respondents from Small Medium Enterprise firms engaged in beverage involved in MBO Program conducted for 2 months. Measurement of work engagement used UWES Scale (Utrecht Work Engagement Scale) developed by Schaufeli and Bakker. The data analysis uses wilcoxon and the results show that MBO program is effective for improving employee work engagement $(-2,135 ; p$ $<0.05)$.

Keywords: $M B O$, management by objectives, work engagement 
Sumber daya manusia merupakan hal yang sangat penting bagi setiap organisasi. Pengelolaan sumber daya manusia yang baik menghasilkan output positif bagi perusahaan. Output nyata dari seorang karyawan adalah kinerja. Berbagai program dibentuk oleh Perusahaan untuk mengelola serta mengembangkan karyawan agar memiliki kinerja yang maksimal. Program-program tersebut dibuat dengan investasi yang besar, dengan harapan setiap karyawan yang berada pada organisasi tersebut dapat optimal serta memiliki kontribusi terhadap perusahaan.

Pemilihan karyawan yang tepat dapat dilakukan melalui seleksi. Karyawan yang memiliki kinerja tinggi dikenal dengan istilah talent. Study yang dilakukan Gallup, menemukan bahwa selain kompetensi karyawan, faktor yang menjadi penting bagi kinerja karyawan adalah engagement atau keterlibatan yang tinggi terhadap organisasi (Herway \& Dvorak, 2014).

International Labour Organization (ILO, 1991) melaporkan bahwa 60\% buruh di kotakota negara berkembang diserap oleh sektor informal dan kegiatan pada usaha kecil dan menengah (UKM). Laporan lain juga menunjukan bahwa peran sektor UKM sangat penting karena mampu menciptakan pasar-pasar, mengembangkan perdagangan, mengelola sumber alam, mengurangi kemiskinan, membuka lapangan kerja, membangun masyarakat dan menghidupi keluarga mereka tanpa kontrol dan fasilitas dari pihak pemerintah daerah yang memadai (ILO, 1991). Di Indonesia, sektor UKM bahkan menjadi tumpuan kehidupan yang semakin besar sejak terjadinya krisis ekonomi yang dimulai pada tahun 1997.

Dari permasalahan tersebut dapat ditarik kesimpulan bahwa komitmen seorang karyawan terhadap organisasi merupakan hal yang sangat penting. Dengan adanya komitmen karyawan diharapkan dapat bertahan dalam waktu lama di organisasi. Selain komitmen terhadap organisasi, dibutuhkan motivasi serta keterlibatan yang mendalam dari seorang karyawan di sebuah organisasi. Hal ini lebih dikenal dengan istilah work engagement.

Work engagement telah menjadi topik hangat dalam beberapa tahun terakhir di perusahaan-perusahaan konsultasi dan dalam dunia bisnis (Saks, 2006). Konsep work engagement sebenarnya merupakan pengembangan dari teknik manajemen lama seperti Organizational Citizenship Behavior (OCB) (Robinson, Perryman \& Hayday 2004). Konsep ini memberikan pemahaman manajer perusahaan bahwa keterikatan karyawan terhadap perusahaan merupakan suatu elemen penting dalam meningkatkan produktivitas dan efisiensi kerja.

Robinson, Perryman dan Hayday (2004) mengatakan bahwa kedua konsep terdahulu yaitu komitmen dan OCB dirasa kurang lengkap, dan di dalam konsep employee engagement, dimuat unsur kesadaran bisnis (business awareness). Rafferty dan Simons (2005) juga membedakan antara konsep employee engagement dengan dua konsep terdahulunya, dimana employee engagement lebih menunjukkan proses saling memberi dan menerima yang menguntungkan antara karyawan dan perusahaan.

Penting bagi perusahaan untuk memperhatikan engagement para karyawannya karena hal tersebut sangat berkaitan erat dengan outcome bisnis, seperti: kesediaan karyawan untuk tetap bekerja di perusahaan, produktivitas, keuntungan, loyalitas dan kenyamanan pelanggan (Markos \& Sandhya, 2010). Semakin karyawan memiliki 
rasa keterikatan yang tinggi dengan perusahaan, maka semakin meningkat pula pertumbuhan pendapatan bisnis tersebut.

Employee engagement merupakan pengembangan dari konsep-konsep sebelumnya seperti kepuasan kerja karyawan, komitmen karyawan, serta perilaku organisasi karyawan. Robinson, et al., (2004) mengatakan bahwa kedua konsep terdahulu yaitu komitmen dan OCB dirasa kurang lengkap, dan di dalam konsep employee engagement, dimasukkan unsur kesadaran bisnis (business awareness). Dengan adanya karyawan yang terlibat secara aktif di dalam perusahaan menandakan bahwa perusahaan tersebut memiliki iklim kerja yang positif. Hal ini disebabkan karena dengan adanya karyawan yang memiliki keterikatan yang baik dengan perusahaan. Dengan demikian karyawan diharapkan memiliki antusiasme yang besar untuk bekerja, bahkan melampaui tugas pokok yang tertuang dalam kontrak kerja mereka.

Schmidt (2004) mengartikan work engagement sebagai gabungan antara kepuasan dan komitmen, dan kepuasan tersebut mengacu lebih kepada elemen emosional atau sikap, sedangkan komitmen lebih melibatkan pada elemen motivasi dan fisik. Meskipun kepuasan dan komitmen adalah dua elemen kunci, secara individu mereka tidak cukup untuk menjamin work engagement, terdapat tema berulang yang menunjukkan work engagement yang melibatkan pekerja yaitu "going extra mile" (akan bekerja ekstra) dan mengupayakan sesuatu untuk pekerjaan di atas apa yang biasanya diharapkan (Clifton, 2002).

Salah satu Perusahaan kecil menengah yang bergerak di bidang beverage adalah PT. X, yang terletak di daerah Yogyakarta. Saat ini PT. X sedang berkembang dengan jumlah karyawan sebanyak 15 orang. PT. X berdiri semenjak tahun 2008. Dengan usia yang relatif baru, permasalahan yang diuraikan di atas tentunya dialami oleh PT X. Demi menjaga kelangsungan dan berkembang menjadi lebih baik, PT. X harus mampu dalam mengelola SDM yang ada.

Wawancara awal yang dilakukan dengan pihak HRD, visi dan misi yang ada diakui pihak HRD masih bersifat sangat konseptual dan global cakupannya, akibatnya para karyawanpun secara umum tidak memahami apa yang diharapkan dari keberadaannya diorganisasi, serta tujuan organisasi secara umum. Akibatnya, motivasi para karyawan masih belum menunjukan harapan dari organisasi. Hal tersebut ditunjukan dari banyaknya waktu kosong karyawan yang tidak digunakan untuk melakukan kegiatan yang produktif. Menurut pihak HRD para karyawan hanya bekerja sekedarnya, tidak menunjukan keinginan untuk menghasilkan kualitas pekerjaan yang lebih baik.

Karyawan yang telah memiliki keterampilan dalam mengerjakan tugas-tugasnya diharapkan dapat bertahan di PT X dalam waktu lama, mengingat sulitnya untuk mencari dan mengembangkan karyawan yang mampu dalam mengerjakan tugas-tugas operasional. Selain itu, kinerja karyawan yang lain diharapkan mampu mendongkrak kinerja organisasi secara menyeluruh.

Robinson, Perryman, dan Hayday (2004) menyatakan bahwa faktor kunci pendorong dari engagement karyawan adalah apabila karyawan dapat merasa dihargai dan dilibatkan. Lebih lanjut, peneliti menyebutkan bahwa dalam penelitian 10.000 karyawan NHS di Inggris, faktor pendorong employee engagement adalah: rasa untuk dihargai dan terlibat, yang didalamnya memuat pengambilan keputusan, dapat menyuarakan 
pendapat, dan peluang untuk berkembang, serta kepedulian perusahaan terhadap kesehatan dan kesejahteraan karyawan.

Dari uraian tersebut, dapat disimpulkan keterlibatan karyawan terutama dalam menetapkan tujuan dapat membantu organisasi untuk mendapatkan kinerja yang optimal dari para karyawan. Salah satu metode penetapan tujuan yang melibatkan partisipasi karyawan adalah Management By Objectives (MBO).

Management By Objective merupakan salah satu metode dalam menetapkan Goal setting. Beberapa teori mengenai Goal Setting dapat dijelaskan melalui goal setting theory yang merupakan bagian dari teori motivasi yang dikemukakan oleh Edwin Locke pada tahun 1978 (Lunenburg, 2011). Teori ini menyatakan bahwa karyawan yang memiliki komitmen tujuan tinggi akan mempengaruhi kinerja manajerial. Adanya tujuan individu menentukan seberapa besar usaha yang akan dilakukannya, semakin tinggi komitmen karyawan terhadap tujuannya akan mendorong karyawan tersebut untuk melakukan usaha yang lebih keras dalam mencapai tujuan tersebut. Menurut Locke dan Latham (dalam Lunenburg, 2011) tujuan memiliki pengaruh yang luas pada perilaku karyawan, kinerja dalam organisasi dan praktik manajemen.

Selain tujuan organisasi, proses $\mathrm{MBO}$ memberikan perhatian pada tujuan pribadi dan karir individu yang selaras dengan organisasi. Prosedur penetapan target memungkinkan partisipasi nyata dari para subordinat dalam penetapan tujuan (Cummings \& Worley, 2005). Dari uraian tersebut dapat disimpulkan bahwa MBO mengakomodir kebutuhan organisasi dan juga individu didalamnya, sehingga dapat menciptakan kepuasan kerja masing-masing individu, dan efektivitas organisasi secara umum.

Dewasa ini, ilmu psikologi banyak mendapatkan kritik karena kajiannya yang dominan pada penyakit mental (Bakker, et al., 2008). Hal tersebut ditunjukan dari jumlah publikasi tema psikologi negatif dan positif dengan rasio 14: 1 (Myers, 2000). Work Engagement merupakan salah satu isu kajian psikologi positif yang perlu untuk diteliti lebih lanjut. Work engagement merupakan hal yang penting, organisasi modern saat ini mengharapkan karyawan mereka lebih proaktif, menunjukan inisiatif, mengambil tanggung jawab bagi pengembangan profesionalisme, dan selalu menunjukan kualitas kinerja yang tinggi (Bakker \& Schaufeli, 2008). Latar belakang yang telah diuraikan diatas, menjadi landasan penulis untuk melakukan penelitian mengenai pengaruh intervensi management by objectives terhadap work engagement di PT X.

Tujuan dari penelitian ini adalah untuk mengetahui efektiftas intervensi Management By Objectives terhadap work engagement pada karyawan. Penulisan ini diharapkan dapat memberikan sumbangan wawasan bidang Psikologi Industri, serta dalam penelitian terapan mengenai peningkatan work engagement melalui intervensi Management By Objectives, khususnya pada industri produksi beverage. Selain itu, penelitian ini diharapkan dapat memberikan masukan bagi perusahaan, khususnya mengenai penggunaan Management By Objectives untuk meningkatkan work engagement di PT X.

Work engagement merupakan topik yang relatif baru. Beberapa penelitian tentang work engagement diantaranya yaitu, Medlin \& Green (2008) yang menetapkan goal setting sebagai antesenden dari employee engagement, workplace optimism dan individual performance. Model penelitian dapat dilihat di Gambar 1. 


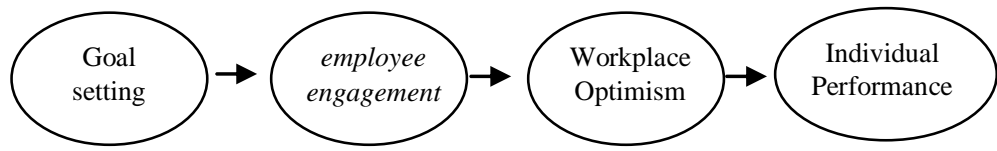

Gambar 1. Model Penelitian Medlin \& Green (2008)

Penelitian lainnya dilakukan Sheemun dkk (2013) dengan model penelitian yang dapat dilihat di Gambar 2.

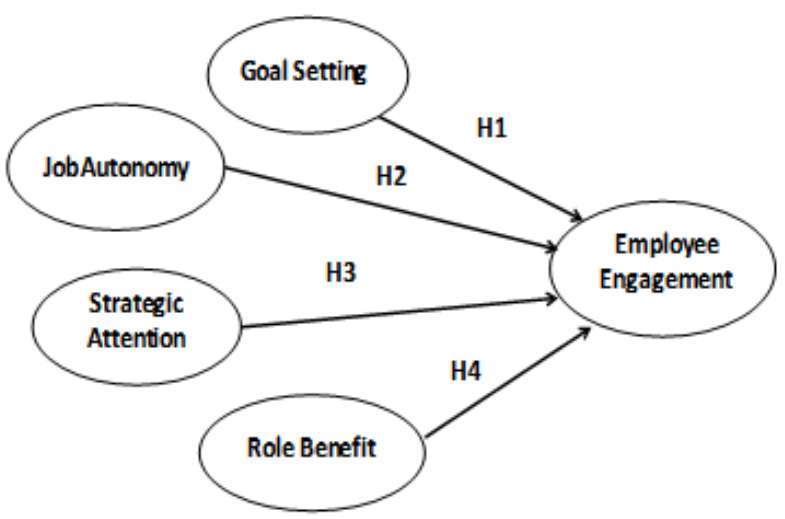

\section{Gambar 2. Model Penelitian Sheemun dkk (2013)}

Pendapat terkait aspek-aspek work engagement juga dikemukakan oleh Schaufeli dan Bakker (2004) yang membagi work engagement dalam 3 dimensi, dan diadopsi sebagai aspek dari skala UWES (Utrecht Work Engagement Scale), ketiga dimensi tersebut yaitu vigor (semangat), dedication (pengabdian), absorption (penyerapan). Vigor didefinisikan sebagai energi yang tinggi dan kondisi mental yang sehat (positif) saat bekerja, keinginan untuk memberikan usaha secara maksimal disertai dengan ketekunan pada situasi sulit. Vigor ditandai dengan adanya semangat yang tinggi, perasaan bergairah dan termotivasi, perasaan gembira saat bekerja, kecintaan terhadap pekerjaan, dan keinginan memberikan usaha yang maksimal dalam bekerja

Dedication diartikan sebagai keterlibatan kuat pada suatu pekerjaan dan merasakan suatu pengalaman yang antusias, menginspirasi, membanggakan, dan penuh tantangan. Dedication ditandai dengan adanya kepedulian yang tinggi terhadap pekerjaan dan lingkungan pekerjaan, keterlibatan yang intensif tidak hanya pada hal-hal yang menjadi tanggung jawab pekerjaan, hubungan interpersonal yang baik di lingkungan kerja, perasaan tertarik dan bangga terhadap pekerjaan, keinginan bekerja dengan sukarela, serta perasaan tertantang terhadap pekerjaan. Absorption merupakan konsentrasi penuh dan terpikat secara senang dengan pekerjaan hingga pekerja merasa bahwa waktu berjalan dengan cepat sehingga terdapat kesulitan untuk lepas dari pekerjaan. Penghayatan yang sepenuhnya pada pekerjaan disebut dengan flow. Flow merupakan sebuah pernyataan mengenai pengalaman yang optimal, yang dikarakteristikkan dengan perhatian yang fokus, pikiran yang jernih, adanya kesatuan tubuh dan pikiran, konsentrasi yang tinggi, kontrol penuh, kehilangan kesadaran diri, distorsi (penyimpangan) waktu, dan kesenangan instrinsik. 
Dalam penelitian ini, penulis menggunakan aspek-aspek tersebut karena menurut peneliti aspek-aspek work engagement dari Bakker \& Schaufeli (2008), yaitu vigor, dedication, dan absorption, komprehensif dan mencakup keseluruhan dimensi work engagement yang dikemukakan peneliti-peneliti sebelumnya.

Management by objective merupakan salah satu metode dalam menetapkan Goal setting. Beberapa theory mengenai goal setting dapat dijelaskan melalui goal setting theory yang merupakan bagian dari teori motivasi yang dikemukakan oleh Edwin Locke pada tahun 1978 (Lunenburg, 2011). Teori ini menyatakan bahwa karyawan yang memiliki komitmen tujuan tinggi akan mempengaruhi kinerja manajerial. Adanya tujuan individu menentukan seberapa besar usaha yang akan dilakukannya, semakin tinggi komitmen karyawan terhadap tujuannya akan mendorong karyawan tersebut untuk melakukan usaha yang lebih keras dalam mencapai tujuan tersebut. Menurut Locke dan Latham (dalam Lunenburg, 2011) tujuan memiliki pengaruh yang luas pada perilaku karyawan dan kinerja dalam organisasi.

Cummings \& Worley (2005) menyatakan bahwa management by objective adalah teknik khusus yang dilakukan organisasi untuk menetapkan tujuan, hal tersebut dilakukan untuk menyelaraskan tujuan Individu dan Organisasi. MBO dapat didefinisikan sebagai suatu sistem manajemen yang di bentuk untuk membantu dalam perencanaan, pengorganisasian, pemecahan masalah, memotivasi, dan kegiatan manajerial penting lainnya. Ini melibatkan partisipasi bawahan dan manajer mereka dalam menetapkan dan menjelaskan tujuan bagi bawahan (Cummings \& Worley, 2005).

Selain tujuan organisasi, proses MBO memberikan perhatian pada tujuan pribadi dan karir individu dan mencoba untuk membuat mereka dan tujuan organisasi yang selaras dan saling melengkapi. Prosedur penetapan target memungkinkan partisipasi nyata dari para subordinat dalam penetapan tujuan (Cummings \& Worley, 2005). Dari uraian tersebut dapat disimpulkan bahwa MBO mengakomodir kebutuhan organisasi dan juga individu didalamnya, sehingga dapat menciptakan kepuasan kerja masing-masing individu, dan efektivitas organisasi secara umum.

Latham \& Yukl (1975) menyatakan bawah komponen dari goal setting terdiri dari tiga hal yaitu, penetapan tujuan itu sendiri, partisipasi dalam penetapan tujuan, dan hasil-hasil dari pengetahuan. Goal setting itu sendiri secara positif mempengaruhi kinerja. Tujuan yang ditetapkan meningkatkan kinerja dan semakin sulit tujuan tersebut dicapai maka semakin baik kinerja yang ditampilkan, dengan catatan dimana tujuan-tujuan tersebut dirasa mungkin dicapai oleh karyawan. Partisipasi dalam menetapkan tujuan memiliki efek campuran pada kinerja. Efektivitas ini tergantung pada intensitas dan jenis partisipasi, dan karakter individu. Sementara pengetahuan tentang hasil adalah karyawan yang mengetahui hasil yang diharapkan dari keberadaannya cenderung meningkatkan tingkat kinerja, serta pekerjaan yang dihasilkan lebih jelas ketika hal tersebut terkait dengan tujuan yang telah ditetapkan.

Ada lima langkah dasar dalam melaksanakan proses MBO (Cummings \& Worley, 2005). Pada langkah pertama dari MBO, anggota kelompok kerja utama menentukan kelompok secara keseluruhan dan tujuan individu lalu menetapkan rencana aksi untuk mencapainya. Jika langkah ini diabaikan atau jika tujuan organisasi dan strategi tidak jelas, efektivitas pendekatan MBO dapat sangat berkurang dari waktu ke waktu. 
Setelah tujuan-tujuan kelompok kerja dan tanggung jawab yang telah ditentukan, perhatian diberikan kepada tugas pekerjaan dan tanggung jawab serta peran individu. Peran secara hati-hati diperiksa agar tidak ada ketergantungan mereka dengan peran lain di luar kelompok kerja.

Tahapan selanjutnya adalah pembentukan rencana aksi untuk tujuan. Pada tahap ini bawahan mengembangkan rencana aksi untuk pencapaian tujuan, baik dalam pertemuan kelompok atau dalam pertemuan dengan manajer langsung. Rencana aksi mencerminkan gaya individu bawahan, tidak dari supervisor.

Tahapan keempat adalah pembentukan kriteria, atau tolak ukur keberhasilan. Pada titik ini, manajer dan bawahan menyepakati kriteria keberhasilan untuk tujuan yang telah ditetapkan - kriteria yang tidak terbatas pada data yang mudah diukur atau dihitung. Alasan yang lebih penting untuk bersama-sama mengembangkan kriteria keberhasilan adalah untuk memastikan bahwa manajer dan bawahan memiliki pemahaman umum dari tugas dan apa yang diharapkan dari bawahan. Sering, pihak yang terlibat permasalahan menemukan bahwa mereka belum mencapai saling pengertian. Bawahan dan manajer mungkin telah menyepakati tugas tertentu, tetapi dalam membahas bagaimana mengukur keberhasilannya, mereka menemukan bahwa mereka belum berkomunikasi dengan jelas. Tiba di pemahaman bersama dan kesepakatan tentang kriteria keberhasilan adalah langkah yang paling penting dalam seluruh proses MBO.

Tahapan terakhir adalah review dan recycle. Secara berkala, manajer melakukan review kemajuan dalam bekerja, baik dalam kelompok yang lebih besar atau dengan bawahan. Ada tiga tahapan dalam proses peninjauan ini. Pertama, bawahan melakukan inisiatif untuk meninjau kemajuan dan membahas prestasi dan kendala yang dihadapi. Selanjutnya, manajer membahas rencana kerja dan tujuan untuk masa depan. Terakhir, setelah rencana aksi yang telah dibuat, diskusi yang lebih umum meliputi ambisi masa depan bawahan dan faktor-faktor lain yang menjadi perhatian.

Perusahaan membutuhkan karyawan yang memiliki dedikasi, kemampuan dan kemauan yang tinggi dalam bekerja. Keseluruhan atribut tersebut terdapat dalam konsep work engagement atau keterlibatan kerja. Sangat penting bagi perusahaan untuk memperhatikan engagement para karyawannya karena hal tersebut sangat berkaitan erat dengan outcome bisnis, seperti: kesediaan karyawan untuk tetap bekerja di perusahaan, produktivitas, keuntungan, loyalitas dan kenyamanan pelanggan (Markos \& Sandhya, 2010). Semakin karyawan memiliki rasa keterikatan yang tinggi dengan perusahaan, maka semakin meningkat pula pertumbuhan pendapatan bisnis tersebut.

Sebuah pemikiran teoritis yang kuat untuk menjelaskan work engagement dapat ditemukan dalam teori pertukaran sosial (Saks, 2006). Teori tersebut menjelaskan bahwa rasa tanggungjawab dihasilkan melalui serangkaian interaksi timbal balik antara pihakpihak yang berada dalam keadaan saling ketergantungan. Sebuah prinsip dasar pertukaran sosial adalah bahwa hubungan berkembang dari waktu ke waktu menjadi percaya, setia, dan saling komitmen selama semua pihak mematuhi aturan pertukaran tertentu (Cropanzano \& Mictchell, 2005).

Aturan pertukaran biasanya bersifat timbal balik sehingga tindakan salah satu pihak menyebabkan respon atau tindakan oleh pihak lain. Misalnya, ketika individu menerima sumber daya ekonomi dan sosioemosional dari organisasi, mereka merasa berkewajiban 
untuk merespon dalam bentuk kontribusi pada organisasi (Cropanzano \& Mitchell, 2005). Hal ini konsisten dengan yang dikemukakan Robinson dkk (2004) dengan mendeskripsikan engagement sebagai hubungan dua arah antara pemilik perusahaan dan karyawan.

Salah satu cara bagi individu untuk berkontribusi bagi organisasi mereka adalah melalui keterlibatan yang mendalam atau engagement. Artinya, karyawan akan memilih untuk melibatkan diri pada tingkat yang tinggi dalam menanggapi sumber daya yang mereka terima dari organisasi. Membawa diri lebih penuh ke dalam peran pekerjaan dan mencurahkan jumlah yang lebih besar dari sumber daya kognitif, emosional, dan fisik adalah cara yang sangat mendalam bagi individu untuk menanggapi tindakan organisasi.

Sumber daya yang diberikan organisasi kepada karyawan berbagai macam bentuknya, diantaranya adalah job resource seperti otonomi, umpan balik hasil kinerja karyawan, kesempatan belajar dan mengembangkan diri. Job resource memegang peranan penting untuk membangkitkan motivasi baik ekstrinsik sebagai alat untuk mencapai goals atau tujuan dapat tercapai (Bakker dkk, 2008).

Latham \& Yukl (1975) menyatakan bawah banyak penelitian membahas dampak positif dari goal setting pada karyawan dalam organisasi. Sistem manajemen, seperti management by objectives, total quality management, dan continous improvement initiatives, menetapkan goal setting sebagai faktor penentu keberhasilan. Management by objectives merupakan salah satu metoda yang dapat digunakan organisasi untuk melakukan goal setting atau menetapkan tujuan (Cummings \& Worley, 2005).

Robinson, et al. (2004), menyebutkan faktor kunci pendorong dari engagement karyawan adalah karyawan dapat merasa dihargai dan dilibatkan. Bentuk penghargaan serta keterlibatan tersebut dipengaruhi oleh empat faktor, diantaranya adalah karyawan dilibatkan dalam (1) pengambilan keputusan, (2) karyawan dapat menyalurkan ide, (3) karyawan dapat mengembangkan pekerjaan, (4) organisasi memperhatikan kesehatan dan kesejahteraan karyawan. Management by objectives merupakan metode penetepan tujuan yang melibatkan karyawan. Sehingga pengambilan keputusan yang berkenaan dengan pekerjaan dilakukan secara bersama antara atasan dan bawahan (Cummings \& Worley, 2005)

Salah satu proses dalam pembuatan $\mathrm{MBO}$ adalah mengakomodir masukan dari bawahan terkait dengan tujuan kelompok yang ditetapkan. Selanjutnya, dari tujuan kelompok tersebut karyawan menetapkan tujuan pribadi untuk menunjang tercapainya tujuan kelompok tersebut. Dari uraian tersebut dapat disimpulkan bahwa MBO mengakomidir masukan dari karyawan terkait dengan tujuan-tujuan yang akan dicapai.

Tujuan yang ditetapkan dalam MBO memberikan pengetahuan yang jelas kepada karyawan, tentang wewenang apa saja yang dimiliki untuk menyelesaikan tujuan-tujuan yang telah ditetapkan dan disepakati bersama. Berbagai penelitian yang dilakukan peneliti sebelumnya menunjukan bahwa goal setting merupakan faktor antecedent yang memicu terjadinya work engagement pada karyawan. Diantaranya adalah Medlin \& Green (2008) dan Sheemun (2013). 
Dari pemaparan diatas, hipotesis yang diajukan pada penelitian ini adalah Terdapat perbedaan tingkat work engagement setelah dilakukan perlakuan management by objectives.

\section{METODE}

\section{Rancangan Penelitian}

Rancangan pada penelitian ini menggunakan eksperimen. Menurut Campbell \& Cook (1979) eksperimen terdiri dari minimal satu perlakuan, ukuran dampak, unit penugasan dan pembanding yang digunakan untuk mengambil kesimpulan adanya perubahan dan untuk mengatribusikan perubahan itu kepada perlakuan sehingga Stouffer \& Campbell (Campbell \& Cook, 1979) merumuskan eksperimen kuasi (quasi experiment) sebagai eksperimen yang memiliki perlakuan, pengukuran dampak, unit eksperimen, namun tidak menggunakan penugasan acak untuk menciptakan pembandingan dalam rangka menyimpulkan perubahan yang disebabkan perlakuan.

Rancangan penelitian yang digunakan dalam penelelitian ini adalah the one group pre test- post teset design yaitu sebuah rancangan yang digunakan dengan cara memberikan perlakuan pada jangka waktu tertentu serta mengukurnya dengan tes sebelum (pre-test) dan sesudah (post test) perlakukan dilakukan. Pada paradigma ini terdapat pre test sebelum diberi perlakuan sehingga hasil perlakuan dapat diketahui lebih akurat, karena dapat membandingkan dengan keadaan sebelum diberi perlakuan (Cambell \& Cook, 1979).

Dari pemaparan diatas maka tampak jelas bahwa management by objectives dapat mempengaruhi tingkat work engagement karyawan. Berikut model penelitian yang diajukan pada penelitian ini.

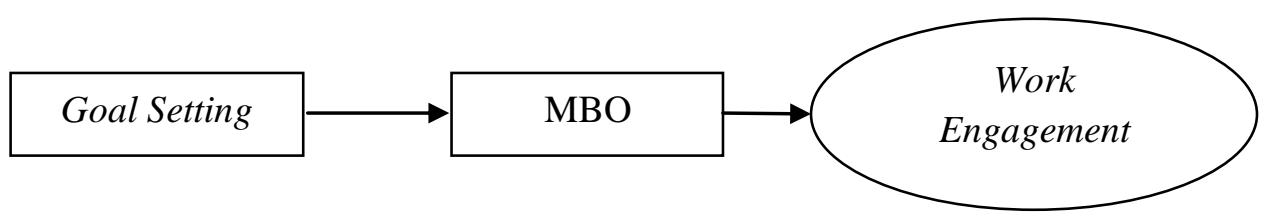

\section{Gambar 3. Model Penelitian}

\section{Subjek Penelitian}

Populasi dan sampel pada penelitian ini adalah seluruh karyawan di PT. X yang berjumlah 13 orang. Teknik pengambilan sampel yang digunakan dalam penelitian ini yaitu purposive sampling. Teknik tersebut dipilih karena dianggap memiliki informasi yang dibutuhkan dalam penelitian (Kumar, 1999). Penelitian ini dilakukan di kantor PT. $\mathrm{X}$ Sleman, Daerah Istimewa Yogyakarta.

\section{Variabel dan Instrumen Penelitian}

Variabel terikat dalam penelitian ini adalah work engagement karyawan dan variabel bebas adalah program management by objective (MBO). Metode pengumpulan data untuk variabel terikat menggunakan Pengukuran work engagement menggunakan skala UWES (Utrecht Work Engagement Scale) yang dikembangkan oleh Schaufeli dan Bakker. Skala digunakan untuk melihat keadaan subjek sebelum dilakukan perlakuan dan setelah dilakukan perlakuan yakni pelatihan kebersyukuran. 


\section{Prosedur dan Analisis Data Penelitian}

Langkah pertama yang dilakukan dalam penelitian ini adalah pemilihan subjek sesuai dengan kriteria, subjek diberikan skala UWES (Utrecht Work Engagement Scale) untuk melihat work engagement pada karyawan sebelum dilakukan program management by objective (MBO). Langkah selanjutnya adalah pelaksanaan program MBO selama 2 bulan pada 12 subjek dari perusahaan usaha kecil menengah. Penelitian ini hanya menggunakan satu kelompok yang akan diberikan perlakuan. Pre-test dilakukan untuk mengetahui tingkat engagement karyawan sebelum diberikan perlakuan atau intervensi. Post-test digunakan untuk melihat kembali perubahan yang mungkin terjadi pada tingkat work engagement karyawan setelah mengikuti program management by objectives. Perubahan dapat diukur dengan membandingkan perbedaan dalam sebuah fenomena atau variebel sebelum dan sesudah diberikan perlakuan. Pada penelitian ini, yang ingin dilihat adalah dampak dari intervensi Management By Objectives terhadap Work Engagement Karyawan PT. X. Sedangkan langkah terakhir adalah analisis data penelitian menggunakan metode Wilcoxon Signed-Ranks Test untuk melihat apakah ada perbedaan skor work engagement sebelum dan sesudah diberikan program management by objectives.

\section{HASIL}

\section{Gambaran Subjek Penelitian}

Berdasarkan hasil statistik tersebut, dapat disimpulkan bahwa terdapat peningkatan pada mean work engagement karyawan PT. X sebelum dan sesudah dilakukannya intervensi management by objectives (MBO). Sebelum dilakukannya program MBO mean work engagement karyawan PT. X sebesar 56,2 sementara pasca penelitian mean work engagement karyawan PT. X 64,4. Sementara itu perolehan rerata pada saat follow up adalah 59,4. Namun pada saat follow up responden F dan MSH telah resign pada bulan Januari. Sementara itu tingkat kategorisasi work engagement sebelum dilakukannya intervensi, sesudah intervensi dan follow up tersaji dalam Tabel 1.

\section{Tabel 1. Deskripsi Hasil Sebelum, Sesudah dan Follow Up}

\begin{tabular}{|c|c|c|c|}
\hline Kategorisasi & Rentang Hasil & Jumlah & Persentase \\
\hline \multicolumn{4}{|l|}{ Pra } \\
\hline Tinggi & $X>64$ & 4 & $33,3 \%$ \\
\hline Sedang & $32 \leq X \leq 64$ & 8 & $66,7 \%$ \\
\hline Rendah & $\bar{X}<32$ & 0 & $0 \%$ \\
\hline \multicolumn{4}{|l|}{ Pasca tes } \\
\hline Tinggi & $X>64$ & 8 & $66,7 \%$ \\
\hline Sedang & $32 \leq X \leq 64$ & 4 & $33,3 \%$ \\
\hline Rendah & $x<32$ & 0 & $0 \%$ \\
\hline \multicolumn{4}{|l|}{ Follow Up } \\
\hline Tinggi & $X>64$ & 8 & $66,7 \%$ \\
\hline Sedang & $32 \leq X \leq 64$ & 4 & $33,3 \%$ \\
\hline Rendah & $X<32$ & 0 & $0 \%$ \\
\hline
\end{tabular}


Berdasarkan data tersebut diketahui sebelum dilakukannya program MBO keadaan engagement karyawan yang berada dalam kategori sedang sebanyak 66,7 \% dan yang berada pada kategori tinggi sebanyak 33,3\%. Pasca dilakukannya program MBO jumlah yang berada dalam kategori sedang mengalami penurunan yaitu sebanyak 33,3\% dan sisanya berada dalam kategori tinggi dengan persentase $66,7 \%$.

Berdasarkan uji analisis wilcoxon signed-ranks test, signifikansi yang diperoleh sebesar $0,03<0,05 \quad(\mathrm{los}=5 \%)$ menunjukan bahwa terdapat perbedaan tingkat work engagemet karyawan PT X sebelum dan setelah dilakukannya program MBO. Dari hasil tersebut dapat disimpulkan bahwa hipotesis yang diajukan dalam penelitian dapat diterima.

Sementara itu sumbangan efektif (effect size) pada penelitian ini sebesar 31,33\%. Hal ini menunjukan bahwa program intervensi management by objectives memberikan sumbangan efektif sebesar 31,33\% dalam peningkatan work engagement di PT. X. Sementara itu sebesar 68,67 \% lainnya dipengarhui oleh faktor diluar variabel bebas.

\section{DISKUSI}

Menurut Schaufeli, et al. (2002), karakteristik utama karyawan yang engage adalah vigor, dedication dan absorption. Vigor adalah adalah level energi dan resiliensi yang tinggi, adanya kemauan untuk investasi tenaga, persistensi dan tidak mudah lelah. Dedication adalah keterlibatan yang kuat ditandai dengan antusiasme, rasa bangga dan inspirasi. Absorption adalah keadaan terjun total (total immersion) karyawan yang diindikasikan dengan cepatnya waktu berlalu dan sulitnya memisahkan seseorang dari pekerjaannya (Saks, 2006).

Program management by objectives memfasilitasi karyawan dalam membuat dan menetapkan tujuan (goal setting). Program management by objectives yang dijalankan berdampak pada meningkatnya engagement para karyawan di PT. X Ice cream. Hal tersebut sejalan dengan temuan Medlin \& Green (2009) dalam studi pada engagement karyawan bahwa penetapan tujuan yang efektif adalah pendorong kinerja individu.

Pada penelitian tersebut Medlin \& Green (2009) menjadikan goal setting sebagai antesenden dari meningkatnya engagement karyawan dalam bekerja, selanjutnya engagement karyawan mempengaruhi workplace optimism dan pada akhirnya mempengaruhi kinerja individu. Temuan Medlin \& Green (2009) menunjukan bahwa keseluruhan hipotesis yang diajukan diterima, termasuk goal setting yang secara positif berhubungan dengan tingkat engagement karyawan.

Medlin \& Green (2008) melakukan penelitian pada karyawan bisnis retail, real estate dan pegawai pemerintahan dengan jumlah responden sebanyak 426 orang. Penelitian lainnya dilakukan oleh Sheemun, et al. (2013) yang menemukan bahwa variabel yang dapat menjadi antesendent bagi tingkat engagement karyawan adalah goal setting, otonomi dan rule benefit. Penelitian yang dilakukan pada 204 responden tersebut menunjukan peran goal setting secara positif berhubungan dengan engagament.

Perbedaan mendasar penelitian ini dengan kedua penelitian diatas terletak pada perlakuan yang dilakukan berupa management by objectives yang memfasilitasi goal setting. Perbedaan lainnya terletak pada metode dan demografi subjek penelitian. Seperti yang dikemukakan oleh Cummings \& Worley (2005) bahwa management by objectives 
merupakan salah satu metode dalam menetapkan goal setting dengan ciri partisipasi dari karyawan.

Sumbangan efektif dari program management by objectives ini pada peningkatan work engagement adalah sebesar 31,33\%. Sementara 68,67 \% lainnya dipengaruhi oleh faktor diluar program MBO. Meningkatnya work engagement yang terjadi pada karyawan PT. $\mathrm{X}$ dapat ditinjau melalui teori pertukaran sosial. Menurut Saks (2006) teori pertukaran sosial merupakan landasan berfikir yang kuat dalam menjelaskan proses engagement yang terjadi pada seorang karyawan. Teori tersebut menjelaskan bahwa rasa tanggungjawab dihasilkan melalui serangkaian interaksi timbal balik antara pihak-pihak yang memiliki kepentingan. Sebuah prinsip dasar pertukaran sosial adalah bahwa hubungan berkembang dari waktu ke waktu menjadi percaya, setia, dan saling komitmen selama semua pihak mematuhi aturan pertukaran tertentu (Cropanzano \& Mictchell, 2005).

Aturan pertukaran biasanya bersifat timbal balik sehingga tindakan salah satu pihak menyebabkan respon atau tindakan oleh pihak lain. Hal ini konsisten dengan yang dikemukakan Robinson dkk (2004) dengan mendeskripsikan engagement sebagai hubungan dua arah antara pemilik perusahaan dan karyawan. Management by objectives memfasilitasi peserta dalam mengemukakan pendapatnya, menetapkan tujuan pribadi yang relevan dengan tujuan yang lebih besar sehingga komitmen individu terhadap tujuan yang ditetapkan meningkat. Para karyawan tersebut diberikan wewenang untuk menetapkan tujuannya sendiri yang relevan dan juga memilih pendekatan dalam menyelesaikan tujuan yang telah dibuat. Management by objectives yang dibuat para karyawan dan disetujui membantu memberikan gambaran kepada karyawan terkait dengan tujuan yang dicapai dari pekerjaan-pekerjaan yang dilakukan.

Cropanzano \& Mitchell (2005) menyatakan bahwa ketika individu menerima dukungan dari organisasi, mereka merasa berkewajiban untuk merespon dalam bentuk kontribusi pada organisasi. Salah satu cara bagi individu untuk berkontribusi bagi organisasi mereka adalah melalui keterlibatan yang mendalam atau engagement. Artinya, karyawan akan memilih untuk melibatkan diri pada tingkat yang tinggi dalam menanggapi sumber daya dan dukungan yang mereka terima dari organisasi yang dalam hal ini dilakukan melalui program management by objectives. Para karyawan membawa diri lebih penuh ke dalam peran pekerjaan dan mencurahkan tenaga yang lebih besar dari sumber daya kognitif, emosional, dan fisik. Keseluruhan hal yang dilakukan tersebut adalah cara yang sangat mendalam bagi individu untuk menanggapi tindakan organisasi (Cropanzano dan Mictchell, 2005).

Program management by objectives yang dijalankan juga sekaligus membantu setiap individu dalam memahami arah organisasi secara menyeluruh. Seperti yang diketahui, visi dan misi yang ada dianggap para karyawan masih terlalu bersifat global. Belum mampu diterjemahkan terutama bagi para karyawan level operator. Hal ini seperti yang dikemukakan Tosi \& Carrol (1990) manfaat program MBO salah satunya adalah membuat setiap individu lebih mengetahui sasaran organisasi. Hal tersebut mendorong meningkatnya engagement karyawan di PT. X seperti yang dikemukakan Taran dkk (2009) engagement terjadi ketika karyawan mengetahui apa yang diharapkan, mendapatkan sumber daya untuk menyelesaikan pekerjaan, memiliki kesempatan untuk berpartisipasi terhadap pengembangan serta mendapatkan umpan balik, dan merasa bahwa kontribusi yang diberikan terhadap organisasi dapat diterima atau diapresiasi. 
Efektifitas program management by objectives yang dilakukan sangat bergantung dari penetapan tujuan yang relevan dan pemilihan strategi yang jelas (Cummings \& Worley, 2005). Program management by objectives yang dilakukan mencakup pemetaan keadaan internal dan eksternal organisasi melalui analisis SWOT. Data-data yang dihimpun dari analisis tersebut mencakup kekuatan, kelemahan, peluang, ancaman dari keadaan internal perusahaan dan juga eksternal. Melalui data-data tersebut pihak-pihak yang berwenang dapat memetakan serta membuat tujuan yang relevan.

Pembahasan mengenai hasil dari SWOT yang dihimpun memakan waktu yang lebih lama dari rencana waktu yang ditetapkan. Pembahasan tersebut dilaksanakan pada pertemuan pertama setalah pembentukan kelompok kerja dilakukan. Setiap koordinator dari masingmasing divisi memiliki argumentasi serta perspektif yang sama terkait dengan permasalahan yang terjadi dalam organisasi. Sikap aktif yang ditunjukan oleh para koordinator divisi menunjukan bahwa masing-masing individu memiliki kepedulian serta antusias dalam membuat perubahan dalam organisasi secara menyeluruh.

Pemaparan hasil SWOT tersebut menjadi acuan bagi manager terutama dalam membuat objectives organisasi secara menyeluruh. Ketepatan objectives yang dibuat sangat bergantung dari kemampuan setiap individu terutama pada bagian top management dalam memetakan keadaan internal maupun eksternal perusahaan. Pada level manajemen objectives dapat dengan mudah di terjemahkan dan dipahami. Para koordinator yang ada dalam organisasi tanpa kesulitan membuat goal bagi masing-masing divisi, sehingga secara umum, keseluruhan objectives yang diusulkan kepada atasan dapat diterima dan dijadikan sebagai objectives bagi masing-masing divisi. Namun demikian, berbeda halnya dengan para subordinat, mereka memiliki hambatan hambatan dalam membuat dan menetapkan tujuan. Menurut para pendukung fasilitator hambatan mereka dalam membuat dan mengisi form MBO adalah kemampuan dalam membuat redaksi, serta membuat tujuan yang SMART (specific, measureable, attanaible, relevant \& time bond).

Pada pembuatan objectives tersebut disepakati juga langkah-langkah serta cara-cara yang dapat digunakan, sehingga karyawan mendapatkan otonomi tersendiri dalam menyelesaikan masalahnya. Program management by objectives yang dijalankan secara umum mendapatkan tanggapan positif dari semua pihak serta menstimulasi sikap aktif dan terlibat secara mendalam dari semua rangkaian proses yang dilaksanakan. Hal ini sejalan dengan temuan Marciano (2010) yang menyatakan bahwa karyawan yang engaged, menunjukkan perilaku seperti mengemukakan ide-ide baru dalam pekerjaannya, bersikap antusias terhadap pekerjaannya, berinisitif, aktif mengembangkan diri, orang lain maupun perusahaan, secara konsisten melampaui tujuan dan harapan yang diemban, mengatasi hambatan dan tetap fokus pada tugas-tugasnya, komitmen terhadap perusahaan.

Sumber daya yang diberikan organisasi kepada karyawan berbagai macam bentuknya, diantaranya adalah job resource seperti otonomi, umpan balik hasil kinerja karyawan, kesempatan belajar dan mengembangkan diri. Job resource memegang peranan penting untuk membangkitkan motivasi baik ekstrinsik sebagai alat untuk mencapai goals atau tujuan dapat tercapai (Bakker, et al., 2008).

Faktor-faktor yang termasuk di dalam job resource di antaranya adalah otonomi (autonomy), dukungan sosial (social support) dan bimbingan atasan (supervisory coaching) serta kesempatan bagi perkembangan profesional (opportunities for professional development) (Xanthoupoulou, et al., 2007). Keseluruhan faktor-faktor yang 
terdapat dalam job resource tersebut secara umum terlingkup dalam program management by objectives. Seperti yang dijelaskan sebelumnya, program management by objectives yang dibuat, memberikan otonomi kepada para peserta berupa keterlibatan dalam pembuatan tujuan pribadi. Para karyawan yang menyusun tujuanpun diberikan kewenangan untuk mengajukan strategi penuntasan. Sementara dukungan sosial yang diberikan berupa persetujuan antara karyawan yang bersangkutan dengan atasan terhadap rencana program yang diajukan. Selain itu, karyawan juga mendapatkan umpan balik secara berkala dalam rangka mengevaluasi tujuan yang telah ditetapkan, dan hal-hal apa saja yang perlu dilakukan untuk mencapai tujuan yang telah dibuat dengan efektif.

Dari analisis yang dilakukan pada setiap individu, terdapat perbedaan dengan arah yang negatif pada salah satu karyawan. Hal tersebut menunjukan penurunan engagement pada karyawan tersebut pasca dilakukannya program management by objectives. Dari wawancara yang dilakukan terhadap pihak management diketahui bahwa management melakukan pemotongan gaji pada karyawan tersebut dikarenakan kelalayan dalam bekerja, sehingga mesin produksi yang diangkut oleh karyawan tersebut jatuh pada saat akan dipindahkan.

\section{SIMPULAN DAN IMPLIKASI}

Berdasarkan penelitian yang serta analisis terhadap data yang dilakukan, dapat disimpulkan bahwa hipotesis kerja yang diajukan diterima, yakni terdapat perbedaan tingkat work engagement sebelum dan sesudah dilakukannya program management by objectives pada PT. X. Tingkat work engagement pada PT. X meningkat pasca dilakukannya program management by objectives.

Adapun saran yang dapat diberikan pada penelitian ini yaitu, 1) program MBO yang akan dilaksanakan oleh peneliti selanjutnya, harus dikonsepkan secara matang dan mendapatkan dukungan dari seluruh elemen dalam organisasi. 2) Memperkaya materi sosialisasi dengan permainan atau simulasi dan menambha waktu sosialisasi sehingga memudahkan peserta dalam memahami program yang akan dijalankan. Hal ini perlu dilakukan karena sebagian responden menyarankan untuk menambah waktu role play cara melakukan wawancara partisipasi agar kemampuan mereka dalam menggali tujuan dan strategi dari subordinat meningkat. 3) Menambah jumlah fasilitator yang menunjang terlaksananya program MBO. Hal ini diperlukan terutama saat pengisian form MBO agar tujuan yang dibuat memenuhi konsep SMART (specific, measureable, attainable. result oriented, time bond). 4) Menambah jumlah waktu pemetaan dan review keadaan organisasi dari data SWOT yang disebarkan sehingga tujuan yang lebih besar relevan dengan sumberdaya organisasi serta keadaan bisnis yang berkembang. 5). Menggunakan kelompok kontrol untuk melihat efektifitas program management by objectives yang di rancang dengan ketat, serta mencoba mengaplikasikannya pada berbagai jenis industry dari berbagai jenis usaha di semua tingkatan. 


\section{REFERENSI}

Bakker, A.B, Schaufeli, W. B, Leiter, N. P., \& Taris, T.W, (2008). Work engagement: An emerging concept in occupational health psychology. Journal Work \& Stress, $22(3), 187-200$.

Bakker, A.B., \& Schaufeli, W.B. (2008). Positive organizational behavior: Engaged employees inflourishing organizations. Journal of Organizational Behavior, 29, 147-154.

Campbell, D. T., \& Cook, D.T. (1979). Quasi-Experimentation, design and analysis issues for field setting. Boston: Hougton Mifflin Company.

Cummings, T. G., \& Worley, C. G. (2005). Organization development and change. 6th Ed. South-Western: College Publishing

Cropanzano, R., \& Mitchell, M.S. (2005). Social exchange theory: an interdisciplinary review. Journal of Management, 31, (6), 874-900.

Herway, J., \& Dvorak, N. (2014). What's More Important: Talent or engagement?.A study with retailer ANN INC. seeks to find the essential ingredients to highperforming managers and employees. http://www.gallup.com/businessjournal/167708/important-talent-engagement.aspx.

ILO .(1991). The Dilemma of the informal sector. Report of the Director General, Part I, the 78th Session of the International Labour Conference, Geneva

Latham, G.P., \& Yukl, G.A. (1975). A review of research on the application of goal setting in organizations, Academy of Management Journal, 18, (4), 824-845

Lunenburg, F. C. (2011). Goal-Setting Theory of Motivation. international journal of management, business, and administration, 15, (1), 1-9

Marciano, P. L. (2010). Carrots and sticks don't work: build a culture of employee engagement with the principles of RESPECT. USA: McGraw Hill.

Markos, S., \& Sandhya, M. S. (2010), Employee engagement: The key to improving performance, International Journal of Business and Management, 5, (12), 89-96

Medlin, B., \& Green Jr, K. W. (2008). The Relationship Among Goal Setting, Optimism, And Engagement: The Impact On Employee Performance. Allied Academies International Conference, 13, (1), 51-56.

Medlin, B., \& Green Jr, K. W. (2009). Enhancing performance through goal setting, engagement and optimism. Journal of Industrial Management \& Data Systems, 109, (7), 943-956. 
Rafferty, A., \& Simons, R.H (2006). An examination of the antecendent of readiness for fine-tuning and corporate transformation changes. Journal of Business and Psychology, 20, (3), 325-3250

Robinson D., Perryman S., \& Hayday S. (2004). The Drivers of Employee Engagement Report 408, Institute for Employment Studies, UK

Saks, A. M. 2006. Antecedents and consequences of employee engagement. Journal of Managerial Psychology, 21, (7), 601-602.

Schmidt, F. (2004). Workplace Well-Being in The Public Sector -A Review of The Literature and The Road Ahead. Public Service Human resources Management Agency of Canada. Ottawa: PSHRMA. (Online) Available:htttp//www.hrmaagrh.gc.ca/hrWh/wlbpseeoppfps/documents/WorkplaceWellBeing.pdf

Sheemun, Y. (2013) Employee Engagement: A Study from the Private Sector in Malaysia. Human Resource Management Research, 3, (1): 43-48. http://article.sapub.org/10.5923.j.hrmr.20130301.09.html\#Ref . Di unduh tanggal : 14 Juni 2015.

Taran, L.C., Shuck, M.B., Gutierrez, C.C., \& Baralt, S. (2009). The role of leadership style in employee engagement. In M.S. Plakhotnik, S.M. Nielsen, \& D.M Pane (Eds.), Proceedings of the eight annual college of education research conference (pp.15-20). Miami: Florida International University.

Tosi, H.L., \& Carrol, S.J (1990) Managing organizational behavior. (2 ${ }^{\text {nd }}$ Edition). New York : Harper Collings Publishers.

Xanthopoulou, D., Bakker, A.B., Demerouti, E. \& Schaufeli, W.B. (2007). The role of personal resources in the job demands-resources model. International Journal of Stress Management, 14, (2), 121-141. 